\title{
Crafted Natures: A Beach as Seen by Its Fishermen
}

\author{
Francisco J. Maya-Rodríguez
}

DOI: 10.21104/CL.2017.2.05

\begin{abstract}
Today, many European cities are still struggling to reinvent their development model in response to the effects of deindustrialization. It is in this context that nature, landscape and heritage are gaining more and more importance within leisure- and tourism-based urban models. This is the case for Cadiz, a small city in southern Spain where La Caleta, a small beach located downtown, has become one of the main tourist icons of the city. Due to its particular location, history and morphology, this small beach boasts a vast diversity of ichthyofauna, and is also an important local heritage site which functions customarily as one of the city's most emblematic, active and dynamic open public spaces. Drawing from the results of an ongoing doctoral thesis, this presentation deals with the local fishermen's notion of nature in order to understand how they make sense of the symbolic and material reconstruction which the beach has undergone, and the position they're assigned in the process. By doing so, I show how this discourse is influenced by urban conflicts derived from the adaptation process taken by the city on its transformation from an industrialto a tourism-based development model.
\end{abstract}

Keywords Urban political ecology, environmental anthropology, urban nature, artisan fishing.

Contact Francisco J. Maya-Rodríguez, PhD., Pablo de Olavide University, Castellar, $n^{\circ} 44 ; 3^{\circ}$ F., 41003, Seville, Spain; e-mail: fjmayrod@upo.es.

Jak citova / How to cite Maya-Rodríguez, Francisco J. (2017). Crafted Natures: A Beach as Seen by Its Fishermen. Český lid 104, 247-257. doi:http:// dx.doi.org/10.21104/CL.2017.2.05 


\section{Introduction}

Cities have rarely been within the scope of Environmental Anthropology. Despite renewed expansion in recent years (Townsend 2009) and the ecological urgency imposed by the advent of the Anthropocene (Pàlsson et al. 2013), from laboratories to indigenous communities, environmental anthropology keeps elaborating most of its ethnographic material from contexts close to the western idea of nature. In parallel with the environmental sub-field, Urban Anthropology has evolved without putting much emphasis on the specific social-ecological dynamics of its field, and even less on the manifold ways people make sense of them - i.e. their symbolic dimension. Described as a "second nature" (Lefebvre 1978), cities have been traditionally depicted as the antithesis of nature, as built-up environments where the artificial was imposed over the organic (Heynen - Kaika - Swyngedouw 2006). Indeed, anthropological research on urban natures has been based on the idea that even when cities are entirely human-made environments, nature still permeates citizens' lives (Rotenberg 2014). These conceptions resemble an ecological imaginary which still "comprises a cluster of dichotomous, ethological and neo-romantic readings of nature" (Gandy 2006: 72). Over the last decade, political ecology and cultural geography have shown a deeper interest into how nature is being reinstalled in post-industrial cities. As Chris Hagerman notes (2007), this reinstallation comes from attempts to make urban settings more habitable and, at the same time, to stimulate new local economies based on services, housing sectors and the so-called creative economies. These are processes which cannot be observed removed from the uneven social differentiation inherent to urban social-ecological systems (Harvey 1996; Heynen - Kaika Swyngedouw 2006; Cook - Swyngedouw 2011). Notwithstanding, while urban political ecology has centred its research on the material and socio-economic aspects of this process, I contend it is necessary to include its symbolic dimension, or to put it more clearly, how people make sense of it. If contemporary western urbanisation is developing according to a naturalistic ontology, in the sense of Descola (1996), then it is relevant to understand how, in the light of sustainable urbanist policies, the displacements in the discursive fringe between nature and culture take place. In order to do this, it becomes necessary to comprehend the ways people perceive their environment and their role in the urban landscape.

In this paper, I present the case of artisanal fishing in La Caleta, a beach located in downtown Cadiz, a city in southern Andalusia (Spain). The ethnographic and historical data I draw upon represent a part of the ethnographical material I collected for my current Ph.D. Thesis. In this research I develop a framework based on spatial theory (Lefebvre 2013 [1974]; Harvey 1996; Massey 2005) and new epistemologies of nature (Escobar 2008, see also Ingold 2008, 2011; Descola 2005; Latour 2004) to analyse the diverse uses of the urban 
coast-scape. By understanding how the practical engagement with it engenders a myriad of ways of perceiving, knowing and valuing the local marine environment, I try to observe how they relate with urban history and policies. The fieldwork was carried out between 2011 and 2014, funded thanks to a fellowship grant from the Autonomous Government of Andalusia.

In the first section of the article, I present a short formal description of the beach. In the second I try to summarize the socio-economic background that helps to explain how the city's transition to a post-industrial economy has affected the current situation of artisan fishing in La Caleta. The last section outlines the way fishermen understand their activities and how their perception is influenced by urban conflicts derived from the adaptation process of the city in the transformation from an industrial- to a tourist-based development model.

\section{La Caleta: a Commonplace}

La Caleta - meaning small cove in Spanish - is located in Cadiz' downtown district and is among its most dynamic and active public spaces. Due to its geomorphologic particularities and its importance in local history, the beach presents a vast plurality of uses which coexist throughout the entire year. Situated to the west, it has $22 \mathrm{~km}^{2}$ of sandy shoreline, flanked by two reefs expanding its surface by approximately one kilometre into the sea on both sides. These reefs constitute the habitat for more than one hundred marine species, thirty-five of them being suitable for fishing or human consumption. Most of them find in the reefs a place for spawning, although the ecological degradation caused by overfishing and urban life dynamics, such as vehicle traffic or the high affluence of visitors during summer, present a serious threat to their survival. In addition to its relative biological significance, the beach has great significance as a heritage site. In ancient times, La Caleta was the entrance to the old city docks. Human presence has been documented here since neolithic times (Kölling et al. 2001), as well as a vast number of shipwrecks from antiquity to the early modern age. Because of its importance as an archaeological site, the former bath house is now the seat of the Underwater Archaeology Center of Andalusia. But its past not only attracts interest from scholars. The discovery of ancient material culture has been a pretext for the formulation of local myths and stories which cast La Caleta in a romantic light, presenting it as the epitome of the city's history.

Its two military fortresses, part of the city's old defensive system, now serve as exhibition centres, an auditorium and as the university marine research center. Along with the bath house, they contribute to the monumental value that local authorities have identified in the beach, comprising one of the main architectural attractions for local tourism. 


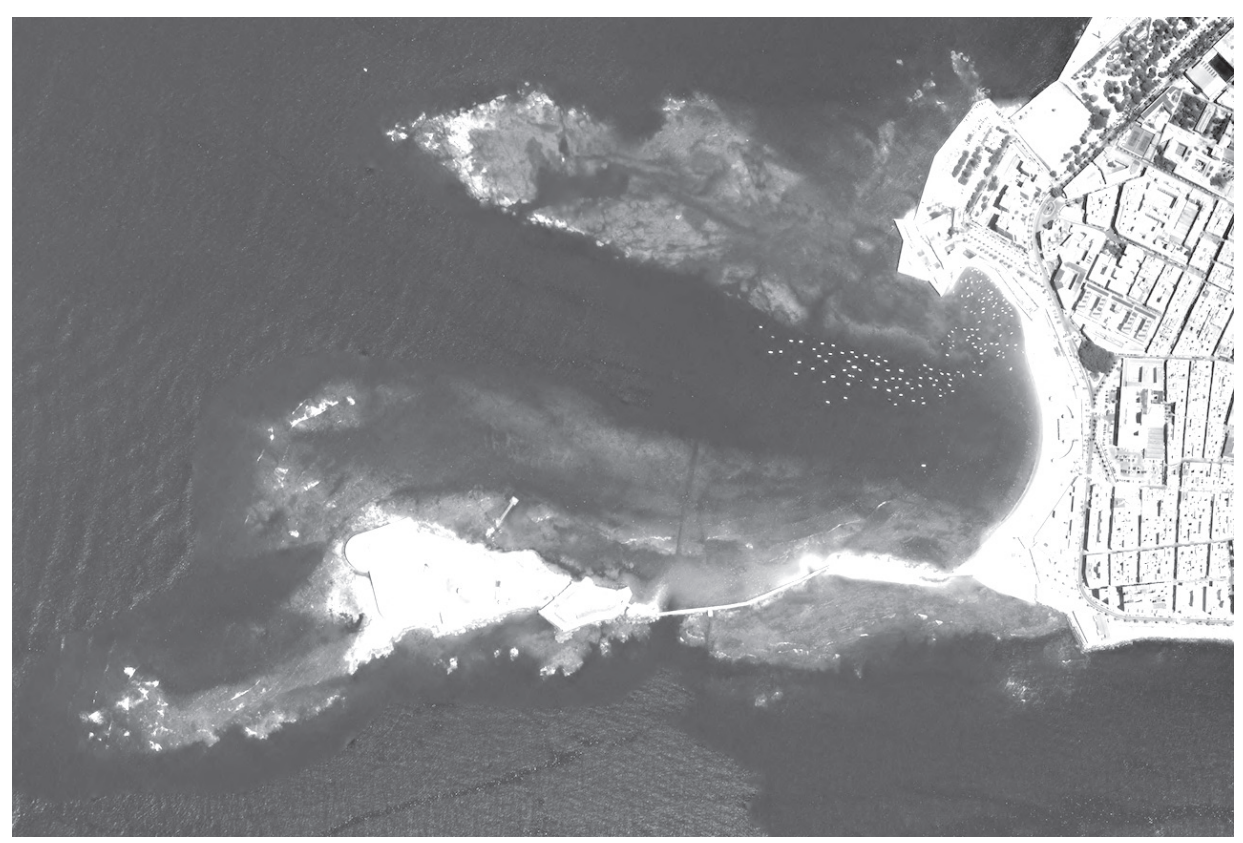

Fig. 1: La Caleta in 2011. Source: REDIAM (Andalusian Network of Environmental Information)

However, above all, La Caleta stands out because of its role as a public space. Cadiz is a tiny peninsula, and because of the lack of free space for new building, the city spatial planners systematically avoided the inclusion of open places and green areas in their designs. Beaches and the waterside cover this shortage. La Caleta has functioned as many parks do in other cities, but in this case, it also serves as a place where a lot of locals learn to socialise, not only with other human beings but also with the rest of the elements of the local marine environment. This sociability is evident in very different activities such as water sports, ball games, or leisure activities such as sunbathing. This is the reason why people say that "La Caleta is [not a beach] but a lot of beaches", implying the idea that each activity conveys a different gaze towards its coastcape.

In this sense, fishing is among the most remarkable activities in the beach's taskscape. The northern reef of the cove provides ships with suitable shelter against the strong eastern winds and storms, and has served as an anchorage for centuries. It was formerly occupied by artisanal fishing ships, which started to disappear in the 1960s, when the city council agreed to build a nautical club on the beach. The modernisation of the sector as well as increasing legal restrictions made artisanal fishing an obsolete and barely profitable activity in the city. Today most ships are recreational boats, yet their number may reach 150 during spring and summer -the most favourable seasons for fishing. This anchorage is not guarded and no authority regulates moorings, 
so no fees are needed in order to tie up a boat, making it an affordable dock for low-income sectors.

But fishing has not only made a visual impact on the coastscape. This activity is responsible for the toponymy of La Caleta, which assigns a name to almost every area, inlet or salient in the beach and its flanking reefs. They serve mainly as landmarks for navigation both at land and at sea, but also as areas which are associated with particular conditions such as clearer waters, heavier winds, lower public exposure or a larger presence of certain species.

Today, while La Caleta has become both materially and symbolically reconstructed as a place to offer leisure activities for tourists and local visitors, the fishermen's local knowledge functions as a key element. It provides the very basis for other ways of inhabiting the beach and making sense of it. However, the question this paper aims to answer is: how do they understand this reconstruction and the position they're assigned in it? In order to do that I need to describe the socio-economic context in which this process unfolds.

\section{Cadiz's Post-Industrial Transition and the Reimagining of Its Heritage}

Being a port city, Cadiz's environmental and urban history is intimately linked to the sea. Maritime trade was its raison d'être and the prime cause of its growth in the 19th century. After the independence of the Spanish colonies, trade declined and so did the city. In the 1960s, the Franco authorities decided to invigorate the city economy through several expansion plans. In short, these projects set aside two expansion areas in the isthmus of the peninsula; the eastern side was reserved for industrial facilities, mostly linked with the shipbuilding sector and aimed at the global market. The areas near the western beach were mainly set aside for vacation housing developments (JiménezMata - Malo 1995). However, the downtown district with its serious infrastructural problems was disregarded in favour of the new areas of expansion (Pérez-Serrano 1993). It was the main residential core of the city, mostly populated by working-class people living in overcrowded tenement houses.

The implementation of the city expansion projects not only stipulated how the city's land would be used, but it also stated how the coastal line would be used. In accordance with the expansion strategy, local authorities converted the largest city beach - La Playa Victoria - to the city's main touristic attraction, while La Caleta was designated a "popular beach" - no access fees were required - and it was intended for the working classes. In those days, the beach had a dumping site on its south side, so garbage flooded into its waters along with the tidal flows. Local authorities had also designated the beach as a place where the nearby small factories and workshops could discard their waste and clean their tools.

In the 1980s, thanks to its industry, the city evolved and the population increased, reaching 157,000 , and was running out of land to build on. In the 
1990s, the industrial sector started to show severe symptoms of decline, as demand for heavy cargo ships slackened due to the new global markets and the opening of new trade routes (Gutiérrez - Florido - Roca 2009). As a consequence, the shipyards started to close down, and mechanisms for liberalising their functions were created. Therefore, faced by significant social opposition, the city started its post-industrial transition, motivated mostly by the lack of competitiveness. This process became consolidated in the 2000s with the closure of the General Motors factory, the last large factory in the city. In response to the local economic stagnation, the authorities started to develop the same adaptation strategies carried out by larger cities. In their attempt to attract external investors and consumers, they tried to stimulate private investment in the housing, tourist and leisure sectors. Local narratives and images of the city were reinvented and placed on the global network through city branding in order to expand choice and value. All of this implied a rereading of the local heritage and the city's marine environment, which was clearly expressed in the land-use plan approved in 2008 by the city council. This plan included the redesign of La Caleta beach and its surroundings, even proposing the construction of a dock for cruise ships and the conversion of a large building from the late eighteenth century into a luxury hotel. The announcement of the new dock rapidly provoked a reaction among the local population, who, in an attempt to stop the plan, started a petition to declare the beach a natural monument. Although this was rejected, funding cuts and the unpopularity of the project led to its cancellation by the city council.

The outcome of these processes did little to alleviate the painful issue of structural unemployment affecting the city. According to data provided by the Spanish National Institute of Statistics, in 2005 the Spanish unemployment rate was $8 \%$, while in Cadiz it reached $33 \%$. Today, in the wake of the country's financial collapse, the national percentage has risen to $22 \%$, while Cadiz remains at 33\%, with the neighbourhoods surrounding La Caleta being among the most affected by the problem.

\section{The Transition of Artisan Fishermen}

Now to return to my previous question. How have artisanal fishermen been affected by the changes in La Caleta? Today, they are faced with the implementation of severe regulatory measures which favour the industrial exploitation of fisheries and criminalise street vending, which in conjunction with high tax rates, makes theirs a barely profitable activity. These are combined with municipal ordinances to make room for a "neat and clean" tourist experience. For example, the selling of daily fish catches is no longer allowed in the streets, which in the past provided many of these artisan fishermen with a secure source of income in the context, as I explained before, of high unemployment rates and economic uncertainty. Several political measures are used 
to repress such "smelly, noisy and visually disturbing" practices. For example, health and safety regulations are used as a means of economic coercion against fishermen, who are threatened with substantial fines if they continue selling fish on the street, in addition to losing the time and money they invested in their catches.

As a consequence, professional dedication has almost disappeared. However, in the absence of job opportunities some keep trading just within the bounds of the law, declaring themselves as recreational fishermen to the authorities. These are men between 30 and 70 years old. Most of them are unqualified, long-term unemployed people from families with a fishing tradition, or retired workers with very low incomes. Many of them say they learnt to fish during childhood by observing fishermen while skiving off school located at the border of the beach's waterfront. Others say that they inherited their parent's trade. The younger were initiated using rods, standing over rock or concrete salients at the waterfront. Usually working alone, they may have close partners with whom they work on certain tasks. Generally, it was through a second fishermen that they started to fish on boats, until they decided to invest some money in a second-hand boat. Their secrecy reinforces the absence of any organisational structure or fishermen's guild, while they keep using the knowledge and tools of artisan fishermen in smaller ships.

The adjective 'furtive' doesn't worry them, and they are happy to call themselves pirates or predators, sometimes casting their words in a defiant and honourable manner. As technology is too expensive in relation to the profit from their catches, they are generally very low-tech, which is why sport fishermen pejoratively call them "Romans", referring to the antiquity of their techniques. Indeed, admitting to using GPS is embarrassing and most of them say that they navigate the old way, looking for signs on the horizon to guide them in the sea. In this sense, they show high esteem for the so-called ancientsretired professionals who still come to the beach and are honorary members of the maritime club, and whose knowledge the fishermen praise. Those who keep doing things the ancient way also make their own fishing tackle, as longline fishing is the most commonly used technique on boats.

Given its barely legal status, the fishermen find themselves engulfed in environmental narratives that portray them as delinquents, concealing the socio-economic background of this problematic situation. This background includes conservation policies that aim to preserve the marine environment from ecological damage, and make fishermen take responsibility for the damage caused by higher impact activities such as intensive local industrial fishing, sea-floor dredging works, or mass tourism.

For them, the direct consequence of the process is twofold. On the one hand, it means a progressive alienation from the beach and from their customary way of making a living. On the other, with the recognition of the fishermen's knowledge and their heritage as valuable attributes of the coastscape, 
they become fetishized to fill the memorial gap between the city and its marine environment, caused by its transition to a new economy. The confrontation between different practices and ways of using the environment is encapsulated in radically different ways of understanding and representing the environment. These opposing environmental discourses are therefore heuristic devices that provide a window to the uneven power relations behind the conflict.

In other words, while their presence is one of the beach's most distinctive attributes and a key element in the discourse supporting its touristic appeal, their activities are becoming more and more restricted. Putting it in Ingold (1993) terms, they've been fixed to the landscape, but expelled from the taskscape. In this context, artisanal fishermen find themselves trapped in a paradox. This paradox is directly linked to the contradictions entangled in the dual treatment that the beach receives from local authorities, both as a public space and a natural environment.

It is in the ongoing process of carrying on with their own everyday activities that they make sense of it. During the conversations I had with them, many vindicated their labour by claiming their belonging to the same "nature" local authorities say they want to protect. Their notion of nature is not restricted to the biophysical dynamics of aquatic ecosystems, but entangles sociality. It's being is the result of human intervention. While I've documented many conversations where the idea of nature is expressed in this sense, this particular quote of one of my interviewees poetically synthetises the way they make sense of this paradox:

Fisherman: Now I ask you: what would happen to La Caleta if you took away all the fishing boats?

Me: Well, it kind of loses its appeal, right?

Fisherman: What would happen to the beach without the many colours that the boats give to it? Do you think sunsets would be the same? Because there are no two identical sunsets, and it's all because of the boats. Those boats were there before all these other things arrived. And have you ever seen any other city with a beach like La Caleta? With two castles, a school, the public baths and all this nature...?

Me: Do you think there is nature in this beach?

Fisherman: But of course: this is nature that humans have made with their hands. It's a crafted nature.

Me: What do you mean by 'crafted nature'?

Fisherman: Don Fernando Quiñones, ${ }^{1}$ God bless him, said that swimming in La Caleta was both swimming in the sea and swimming in history at the same time. So that's it... Just look at it.

1 Fernando Quiñones (1930-1998) was a local writer who used La Caleta as a scenario and source of inspiration in his writings. His figure is also renowned among the locals for his initiatives to dean the beach and his contribution to the valuation of its. 
The idea of crafted ${ }^{2}$ natures pretty much resembles the way artisan fishermen make sense of the dual state of the beach, implying it is at the same time a natural environment and a place produced by human hands. The nexus among these two dimensions is artisanal fishing, or more precisely the fishing boats. By articulating this narrative, artisanal fishermen are not only making sense of the changes La Caleta has undergone in recent decades but also an attempt at legitimating their role in the landscape, as the link between the city's history and its present.

\section{Conclusions}

In this paper, I've tried to show how artisanal fishermen develop a particular narrative in order to make sense of the displacement their activity has experienced as a result of the paradigm shift taken by local urban policies. These policies imply a new imagination of the relationship the city establishes with its coastal environment. As mentioned in the beginning, in Western societies, the borders between nature and culture, as ontological domains, are not fixed. On the contrary, they're continuously being redefined according to the practical conditions where social action takes place, giving rise to local models of nature (Escobar 2001). As we can see, urban settings are not an exception to this, and the adaptation processes that cities develop under global pressures can contribute to the emergence of social struggles where nature becomes a key rhetorical and practical device. In order to have a better understanding of the conflicts derived from the Nature re-instalment in cities that I mentioned at the beginning of this text, we should not look at the distribution of energetic, material and monetary fluxes as urban political ecology proposes only. We also need to attend to the multiple ways of practical engagement people develop within their local environments and the disruptions caused by the convergence of contradictory normative frameworks.

April 2017

2 Crafted is the English word commonly employed to translate the Spanish adjective artesanal . 


\section{References}

Cook, Ian R. - Swyngedouw, Erik. 2011.

Cities, nature and sustainability. In: Paddison, Ronan - McCann, Eugene (eds.): Cities and social change. London: Sage.

Descola, Philippe. 2005. Más allá de naturaleza y cultura. Buenos Aires: Amorrortu.

Descola, Philippe. 1996. Constructing Natures: Symbolic Ecology and Social Practices. In: Pálsson, Gísli Descola, Philippe. (eds.): Nature and Society: Anthropological Perspectives. London: Routledge: 82-102.

Escobar, Arturo. 2001. Culture sits in places: reflections on globalism and subaltern strategies of localization. Political Geography 20: 139-174.

Escobar, Arturo. 2008. Territories of difference: Place, movements, life, redes. North Carolina: Duke University Press.

Gandy, Matthew. 2006. Urban Nature and the ecological imaginary. In: Swyngedouw, Eric - Kaika, Maria Heynen, Nik (eds.): In the nature of cities. London: Routledge: 62-73.

Gutiérrez Molina, José Luis - Florido, David Roca, Beltrán. 2009. El pueblo en la Calle: Reconversión naval, sindicalismo y protesta popular en el Astillero de Puerto Real. Seville: Centre for Andalusian Studies.

Hagerman, Chris. 2007. Shaping neighborhoods and nature: Urban political ecologies of urban waterfront transformations in Portland, Oregon. CITIES 24(4): 285-297.

Harvey, David. 1996. Justice, nature and the geography of difference. Cornwall: Blackwell.

Heynen, Nik - Kaika, Maria - Swyngedouw, Eric 2006. In the nature of cities: Urban political ecology and the politics of urban metabolism. Nueva York: Routledge.

Ingold, Tim. 1993. The Temporality of Landscape. World Archaeology 25(2): 152-174.

Ingold, Tim. 2008. The perception of the environment: Essays on livelihood, dwelling and skill. London: Routledge.
Ingold, Tim. 2011. Being alive. Essays on movement, knowledge and description. London: Routledge. Jiménez Mata, Juan José - Malo de Molina, Julio. 1995. Guía de arquitectura de cádiz. Sevilla: Consejería de Obras Públicas y Transportes, Dirección General de Arquitectura y Vivienda: Colegio Oficial de Arquitectos de Andalucía Occidental, Demarcación de Cádiz.

Kölling, Martin - Roos, Anna Maria - Kölling, Annette - Schulz, Helga - Schulz, Horst D. - Arteaga, Oswaldo. 2001. El puerto de Gadir: Investigación geoarqueológica en el casco antiguo de Cádiz. Revista Atlántica-Mediterránea de Prehistoria y Arqueología Social 4: 345-416.

Latour, Bruno. 2004. Politics of nature: How to bring the sciences into democracy. Cambridge: Harvard University Press.

Lefebvre, Henri. 1978. El derecho a la ciudad. Barcelona: Amorrortu.

Lefebvre, Henri. 2013. La producción del espacio. Barcelona: Capitán Swing Libros. (Original work published 1974)

Massey, Doreen. 2005. For space. Londres: Sage.

Pálsson, Gísli - Szerszynski, Bronislaw Sörlin, Sverker - Marks, John - Avril, Bernard - Crumley, Carole - Weehuizen, Rifka. 2013. Reconceptualizing the 'anthropos' in the anthropocene: Integrating the social sciences and humanities in global environmental change research. Environmental Science \& Policy 28: 3-13.

Pérez Serrano, Julio. 1993. Formación y desarrollo del espacio urbano en Cádiz: Un modelo genético para su estudio. Gades 21: 107-126.

Rotenberg, Robert. 2014. Nature. In: Nonini, Donald M. (ed.): A Companion to Urban Anthropology. Oxford: Willey-Blackwell: 383-393.

Townsend, Patricia. 2009. Environmental Anthropology: From Pigs to Policies. Prospect Heights: Waveland Press. 


\section{Umně vytvořená příroda: Pláž viděná pohledem místních rybářů}

Mnoho evropských měst se dodnes potýká s dopady deindustrializace, kvůli nimž se pokouší přeměnit svůj model rozvoje. Právě v tomto kontextu příroda, krajina a kulturní dědictví získávají stále více na důležitosti, především v rámci volnočasových a turistických městských modelů. To je i případ Cadizu, malého města v jižním Španělsku, kde se La Caleta, malá pláž u centra, stala hlavní turistickou ikonou města. Díky své specifické poloze, historii a tvaru se tato plážička jednak může chlubit vysoce rozmanitou rybí populací, jednak představuje důležité lokální kulturní místo, které funguje jako jeden z nejcharakterističtějších, nejaktivnějších a nejdynamičtějších veřejných prostorů města. Tento příspěvek, který vychází z výsledků ještě nedokončené dizertační práce, se zabývá dojmy rybářůn, které mohou zprostředkovat jejich způsob chápání symbolické i materiální rekonstrukce, jíž pláž prošla, a jakou při tomto procesu oni hráli roli. Tímto mohu poukázat, jak je diskurz ovlivněn urbánními konflikty vycházejícími z adaptačního procesu, díky němuž město přešlo z průmyslového na turistický model. 